\title{
Optimization of activities of road construction company based on lean manufacturing tools
}

\author{
Anna Minnullina ${ }^{1 *}$, Natalya Solopova ${ }^{2}$ \\ ${ }^{1}$ Industrial University of Tyumen, Volodarskogo St., 38, Tyumen, 625000, Russia \\ ${ }^{2}$ Moscow State University of Civil Engineering (National Research University), Yaroslavskoye \\ Shosse, 26, Moscow, Russia
}

\begin{abstract}
The article proposes an algorithm for implementation of lean manufacturing in relation to a company in the road construction industry. The concept of lean manufacturing involves the possibility of using several tools at the same time to solve the problems and losses encountered during construction and installation works. The results of testing a tool such as a $5 \mathrm{~S}$ system in a road construction company are presented to confirm simplicity and effectiveness of the proposed recommendations.
\end{abstract}

\section{Introduction}

In modern conditions of economic development, enterprises of various industries are constantly forced to adapt and improve business organization. So, the management of large Russian companies often makes the decision to apply the principles of lean production in order to increase the efficiency of production activities. As a rule, it happens due to the active dissemination of information about the successful experience of European and American companies in various industries in the implementation of individual lean manufacturing tools.

Large industrial companies such as Russian Railways OJSC, Sberbank PJSC, KAMAZ PJSC, Rosatom State Corporation and many others also have experience in implementing this concept in Russia.

However, despite the real results of the concept, such as increased labor productivity, improved product quality, reduced rejects and production time, many top managers emphasize the difficulties encountered in its implementation. In most cases, these difficulties were caused by a number of problems, such as: low staff involvement, making mistakes in instructions and regulatory documents, technical impossibility of using concept tools in the production process. At the same time, it must be emphasized that many companies, when introducing and once using the tools of the lean manufacturing concept, without receiving a visible positive effect and quick results, subsequently return to the original version of the established production process.

In order to optimize the activities of road construction industry companies on the basis of lean manufacturing tools, an analysis of a number of domestic and foreign sources was carried out to identify the features of the use of concept tools in Russian practice and the

*Corresponding author: minnullinaay@ yandex.ru 
reasons for abandoning it.

Most authors agree that it is necessary to devote significant attention when introducing lean manufacturing to such elements of a company's development as culture, organizational structure and employee motivation [1-6]. At the same time, the issues of adapting lean manufacturing in Russian companies and management issues are described in detail in the works of such authors as I.Yu. Belyaeva N.S. Davydova, A.N. Gracheva, I.A. Gorina, S. Zinchenko, E.V. Kondratiev, K.O. Safronov et al. [3,5,7-20]

It is important to emphasize that in order to standardize the terminology and conceptual framework of the concept, in 2010 a working group was created on the initiative of Center Priority CJSC, their results were reflected in GOSTs for lean manufacturing (51897-2011, 56020-2014, 56404-2015, 56406- 2015, 56407-2015). This was a serious step in integration of the principles of the concept in the practice of Russian companies.

Despite the fairly widespread practical implementation of the concept in domestic and foreign companies, there is no mention of positive experience of using the concept tools at the enterprise of the road construction industry as one of the most material-intensive and costly in the world.

In this regard, the need has arisen for a theoretical and applied study of lean manufacturing as the basis for optimizing the activities of a road construction company.

\section{Methods}

When creating an algorithm for implementing the concept of lean manufacturing, it is important to identify the main production problems that a road construction company faces, including following:

1) large volumes of consignments of material resources that are stored in an open and closed way;

2) insufficient loading of specialized equipment, which is most often associated with the seasonality of work performed and frequent repairs;

3) significant number of movements and transportation;

4) insufficient staff load;

5) high flow time of individual business processes.

Specific production problems of a road construction company can be solved with a separate tool or a set of lean manufacturing tools, the main ones being distinguished (Figure 1):

- standardization of work;

- organization of workspace (5S);

- Value Stream Mapping (VSM);

- visualization;

- single-minute exchange of dies (SMED);

- protection against unintentional errors (poka-yoke);

- prevention of occurrence of unintentional errors and their prompt elimination until the operation is stopped, so that the inappropriate part does not fall onto the next;

- structured information system that regulates the processes of supplying production and supplying the desired volume of products to the consumer (Kanban);

- total productive maintenance (TPM). 


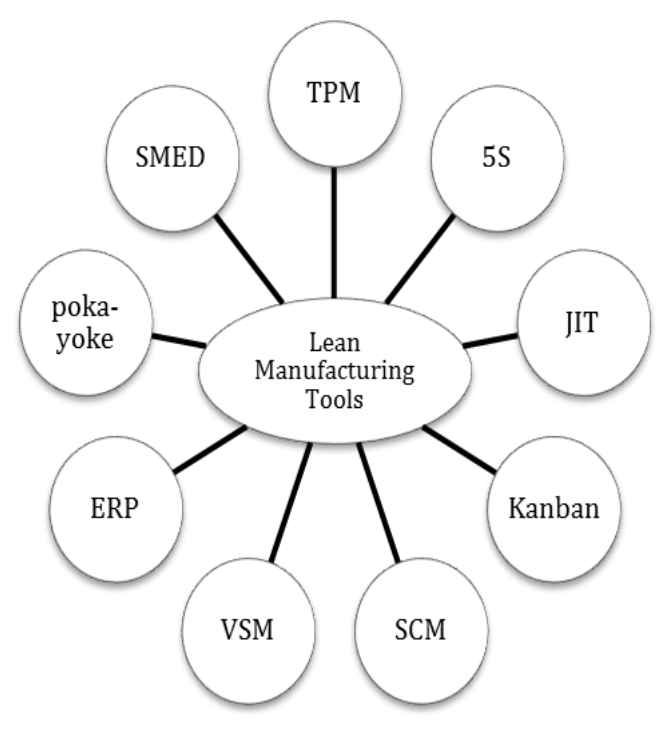

Fig. 1. Lean manufacturing tools.

When implementing lean manufacturing, the initial step is to identify production problems and types of losses using mapping. Mapping is used as a tool for visualization and analysis of material and information flows in the process of creating value from a supplier to a consumer. At the same time, production losses can be detected only in one way - by going step by step along the production site all the way from the order to the delivery of the road construction object. In this process, all employees of the company who in any way affect the efficiency of this stream should be involved.

The whole algorithm for implementing lean production in a road construction company is presented in Figure 2. 


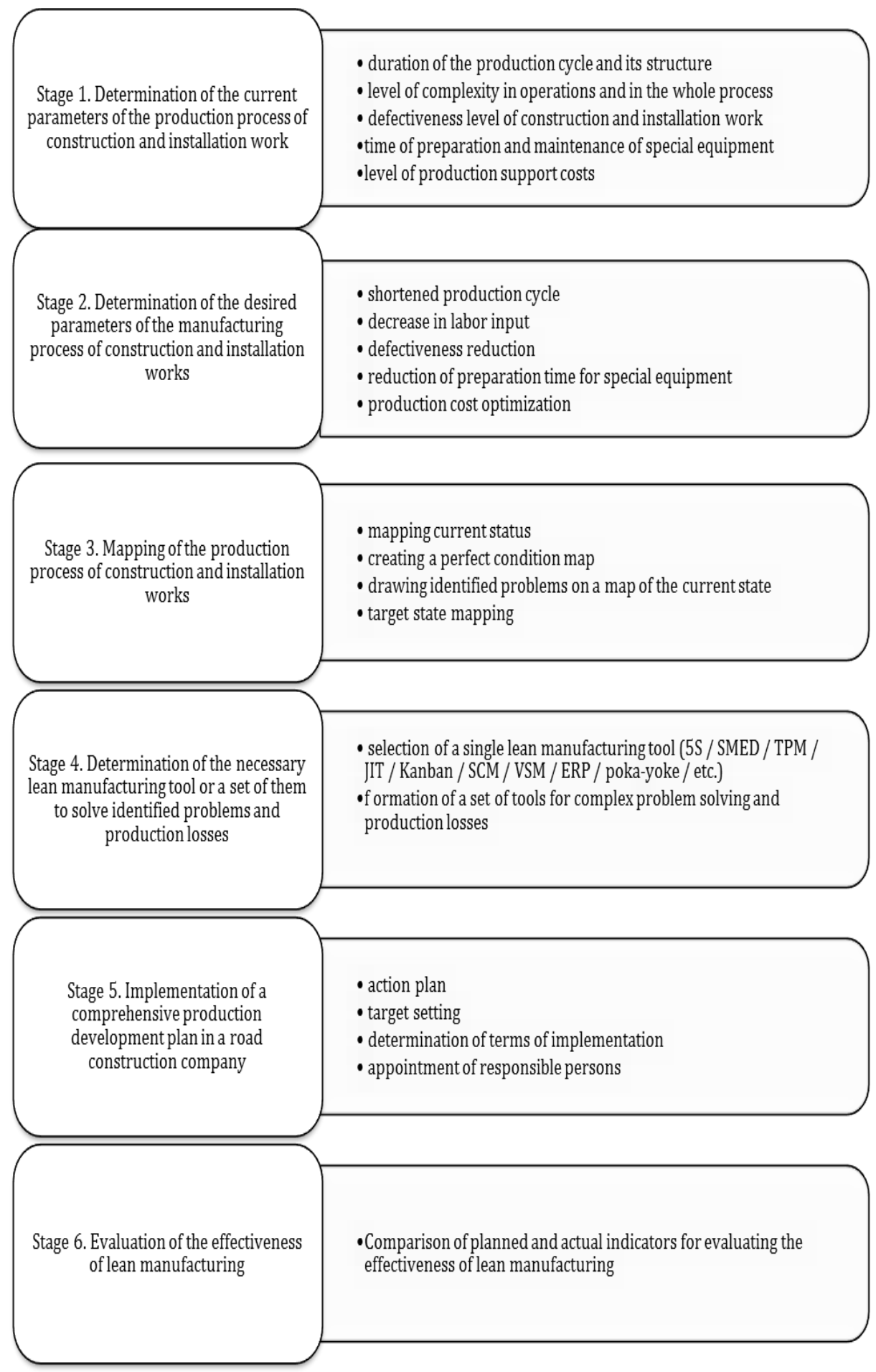

Fig. 2. Algorithm for implementing lean manufacturing in a road construction company.

The proposed algorithm for the implementation of lean manufacturing in a road 
construction company is based on the assumption that one of the key environmental factors affecting the level of competitiveness of a company in the road construction industry is the duration of construction and installation works. In this regard, when determining problems and production losses, it is important to take into account the dependence of this factor on the duration of public procurement process cycles, as well as pre-project and project work.

\section{Results}

In order to test the proposed recommendations, current parameters of the production process were assessed and problems of production activities were mapped in the road construction company DRSU-1 TODEP JSC, which carries out construction and installation works in the Tyumen region.

Mechanical repair workshop of the enterprise (MRW), which has several sections on its territory: a tire fitting section, a locksmith section, an electrical section, was chosen as a reference section.

The list of identified problems in the reference area "repair and mechanical workshop" is presented in table 1.

Table 1. Identified problems in the reference section "repair and mechanical workshop" DRSU-1 JSC TODEP.

\begin{tabular}{|c|c|c|}
\hline $\begin{array}{l}\text { Section of } \\
\text { MRW }\end{array}$ & $\begin{array}{c}\text { № of } \\
\text { the } \\
\text { problem }\end{array}$ & Definition of the problem \\
\hline \multirow{6}{*}{ Tire service site } & 1 & $\begin{array}{l}\text { There are no standards for the storage of consumables, tooling } \\
\text { tools in the work area }\end{array}$ \\
\hline & 2 & $\begin{array}{l}\text { There are no schedules for cleaning the working area of the } \\
\text { section }\end{array}$ \\
\hline & 3 & $\begin{array}{l}\text { There is no standard for wheel bumping work for drivers when } \\
\text { the tire operator is absent, which leads to a tire rush }\end{array}$ \\
\hline & 4 & $\begin{array}{c}\text { Tire repair takes place on the floor, on knees } \\
\text { There is no special workplace for carrying out these works, which } \\
\text { leads to an increase in labor intensity }\end{array}$ \\
\hline & 5 & $\begin{array}{l}\text { Damaged tires are for repair, without transmitting information, } \\
\text { from whom the tire is, what problem and by what date it is } \\
\text { necessary to repair, which leads to an increase in the time for } \\
\text { work }\end{array}$ \\
\hline & 6 & $\begin{array}{l}\text { There is no visual standard for culling tires. The long process of } \\
\text { approval of culling of the wheel or its suitability for further } \\
\text { operation. In case of repair of a wheel with high tread wear, it can } \\
\text { lead to tire rupture and accident }\end{array}$ \\
\hline \multirow{6}{*}{ Locksmith site } & 7 & $\begin{array}{l}\text { Large amount of unused material, unsuitable raw materials, tools, } \\
\text { etc. in the working area of the section }\end{array}$ \\
\hline & 8 & $\begin{array}{c}\text { There are no standards for the storage of consumables, tools, } \\
\text { equipment in the work area }\end{array}$ \\
\hline & 9 & $\begin{array}{l}\text { Long search for the necessary tools, materials, equipment for } \\
\text { repair work, high probability of tool loss }\end{array}$ \\
\hline & 10 & $\begin{array}{l}\text { There is no possibility of accounting for the consumption of used } \\
\text { material, kits for repair work }\end{array}$ \\
\hline & 11 & $\begin{array}{l}\text { When repairing equipment, the working tool is scattered on the } \\
\text { floor, which leads to its loss, pollution, as well as to an increase in } \\
\text { the complexity of work }\end{array}$ \\
\hline & 12 & $\begin{array}{l}\text { The entire working tool is scattered around the site, which leads to } \\
\text { unnecessary movements of workers }\end{array}$ \\
\hline
\end{tabular}




\begin{tabular}{|c|c|c|}
\hline \multirow{6}{*}{$\begin{array}{l}\text { Electrotechnical } \\
\text { site }\end{array}$} & 13 & $\begin{array}{c}\text { Large amount of unused material (wires, hardware, residues from } \\
\text { work performed) in the working area }\end{array}$ \\
\hline & 14 & Reassortment of consumables, tools in the work area \\
\hline & 15 & $\begin{array}{c}\text { There are no standards for the storage of consumables, tools, } \\
\text { equipment in the work area }\end{array}$ \\
\hline & 16 & $\begin{array}{l}\text { There are no visualizations of storage areas for materials needed } \\
\text { for work }\end{array}$ \\
\hline & 17 & $\begin{array}{l}\text { Storage locations for LED signs are not fixed by type of work, } \\
\text { readiness for work or being under repair }\end{array}$ \\
\hline & 18 & $\begin{array}{l}\text { Storage locations for batteries are not fixed by readiness status or } \\
\text { being under repair, or by their readiness for use }\end{array}$ \\
\hline \multirow{6}{*}{$\begin{array}{c}\text { Mechanical } \\
\text { Repair } \\
\text { Workshop }\end{array}$} & 19 & Reassortment of metal by type of assortment \\
\hline & 20 & There are no schedules for cleaning the workshop \\
\hline & 21 & $\begin{array}{l}\text { The working form has a high degree of contamination. No wash } \\
\text { of working form }\end{array}$ \\
\hline & 22 & $\begin{array}{l}\text { In case of an emergency stop of special equipment at the site of } \\
\text { construction and installation works and maintenance of roads, } \\
\text { there is a long and uncontrolled (in quality) repair to replace } \\
\text { damaged consumables, which leads to downtime of the entire } \\
\text { production process (construction and installation work), idle } \\
\text { speed of special. equipment to MRW (maintenance of roads) and } \\
\text { an increase in the volume of work when special equipment leaves } \\
\text { the line }\end{array}$ \\
\hline & 23 & $\begin{array}{l}\text { There is no daily inspection of special equipment in the winter, } \\
\text { which leads to an emergency exit of special equipment on the line }\end{array}$ \\
\hline & 24 & $\begin{array}{l}\text { No technical inspection of special equipment located on the } \\
\text { construction and installation works to prevent emergency stop }\end{array}$ \\
\hline
\end{tabular}

Losses identified during the assessment of the current state, such as waiting, excess traffic, defects, it was decided to exclude using the system of rational organization of the workplace 5S. This system assumes the presence of following elements:

1) "sort", i.e. distribution of objects of labor in the workplace by degree of suitability;

2) "set in order";

3) "shine";

4) "standardize";

5) "sustain" i.e. improvement and formation of industrial culture.

In this regard, an algorithm for step-by-step implementation of the $5 \mathrm{~S}$ system was formed on the reference section "mechanical repair workshop" DRSU-1 of TODEP JSC:

Stage 1 (Sort):

1. Make a list of items necessary and unnecessary;

2. Dispose of unsuitable materials, tools, devices, etc.

Stage 2 (Set in order):

1. Define the criteria and principles of systematization (storage rules);

2. Find for all items its permanent storage;

3. Mark, visual designation:

- storage areas for tools, materials, blanks;

- storage areas for personal protective equipment;

- storage areas for cleaning equipment.

4. Visualize unsafe zones (there is the possibility of tripping, cutting, bumping);

5. Carry out an audit after implementation of the stages "Sort" and "Set in order"

Stage 3 (Shine): to develop and implement reminders for cleaning jobs and the entire area of the machine workshop (location and frequency) and familiarize the personnel with it. 
Stage 4 (Standardize):

1. Develop rules with fixing the frequency and responsibility for cleaning and cleaning checks;

2. Visualize the rules of maintaining the workplace, the storage location of the tool, the material used, according to the $5 \mathrm{~S}$ standards;

3. Standardize and unify all designations (size, color, image of symbols, etc.);

4. Conduct an audit, after implementation of the stages of "Shine" and "Standardize".

Stage 5 (Sustain): to develop and implement audit procedures for the organization of the warehouse facilities in accordance with the principle of the $5 \mathrm{~S}$ system.

Together with the $5 \mathrm{~S}$ workspace organization system, such a lean manufacturing tool as visualization was used. This tool allows to clearly analyze the current state of production processes, reduces the risk of injuries in the workplace, and proper marking reduces the time spent on searches and reduces the number of defects.

For visualization of information, marking, stands, marking and information boards are used.

The action plan to address the identified problems in the reference area "repair and mechanical workshop" is presented in table 2 .

Table 2. The plan of measures to address the identified problems in the reference area "repair and mechanical workshop" DRSU-1 JSC TODEP.

\begin{tabular}{|c|c|c|c|}
\hline Site of MRW & $\begin{array}{l}\text { № of the } \\
\text { problem }\end{array}$ & Problem solving measures & Event designation \\
\hline \multirow{6}{*}{ Tire service site } & 1 & \multirow{2}{*}{$\begin{array}{l}\text { Introduce the } 5 \mathrm{~S} \text { system in the } \\
\text { workplace step by step }\end{array}$} & \multirow{2}{*}{ A } \\
\hline & 2 & & \\
\hline & 3 & $\begin{array}{l}\text { Develop a visual SOP for wheel } \\
\text { bumping for drivers in the } \\
\text { absence of a tire changer. Place it } \\
\text { in the work area }\end{array}$ & B \\
\hline & 4 & $\begin{array}{l}\text { Design and install a stand for tire } \\
\text { repairs. Bring lighting to the } \\
\text { workplace and install a tool stand }\end{array}$ & $\mathrm{C}$ \\
\hline & 5 & $\begin{array}{c}\text { Develop and implement } \\
\text { application cards for repair work } \\
\text { on tires. Mark on the floor "for } \\
\text { repair", "ready" }\end{array}$ & $\mathrm{D}$ \\
\hline & 6 & $\begin{array}{l}\text { Develop and implement a visual } \\
\text { standard for culling wheels }\end{array}$ & $\mathrm{E}$ \\
\hline \multirow{6}{*}{ Locksmith site } & 7 & \multirow{4}{*}{$\begin{array}{l}\text { Introduce the } 5 \mathrm{~S} \text { system in the } \\
\text { workplace step by step }\end{array}$} & \multirow{4}{*}{$\mathrm{F}$} \\
\hline & 8 & & \\
\hline & 9 & & \\
\hline & 10 & & \\
\hline & 11 & $\begin{array}{c}\text { Purchase a tool box for } \\
\text { equipment repair work } \\
\text { Place in it all the necessary tools } \\
\text { for locksmithing }\end{array}$ & G \\
\hline & 12 & $\begin{array}{l}\text { Redevelop work site with the } \\
\text { choice of optimal location of } \\
\text { jobs in order to reduce } \\
\text { unnecessary movement of } \\
\text { workers during work }\end{array}$ & $\mathrm{H}$ \\
\hline \multirow{4}{*}{$\begin{array}{l}\text { Electrotechnical } \\
\text { site }\end{array}$} & 13 & \multirow{4}{*}{$\begin{array}{l}\text { Introduce the } 5 \mathrm{~S} \text { system in the } \\
\text { workplace step by step }\end{array}$} & \multirow{4}{*}{ I } \\
\hline & 14 & & \\
\hline & 15 & & \\
\hline & 16 & & \\
\hline
\end{tabular}




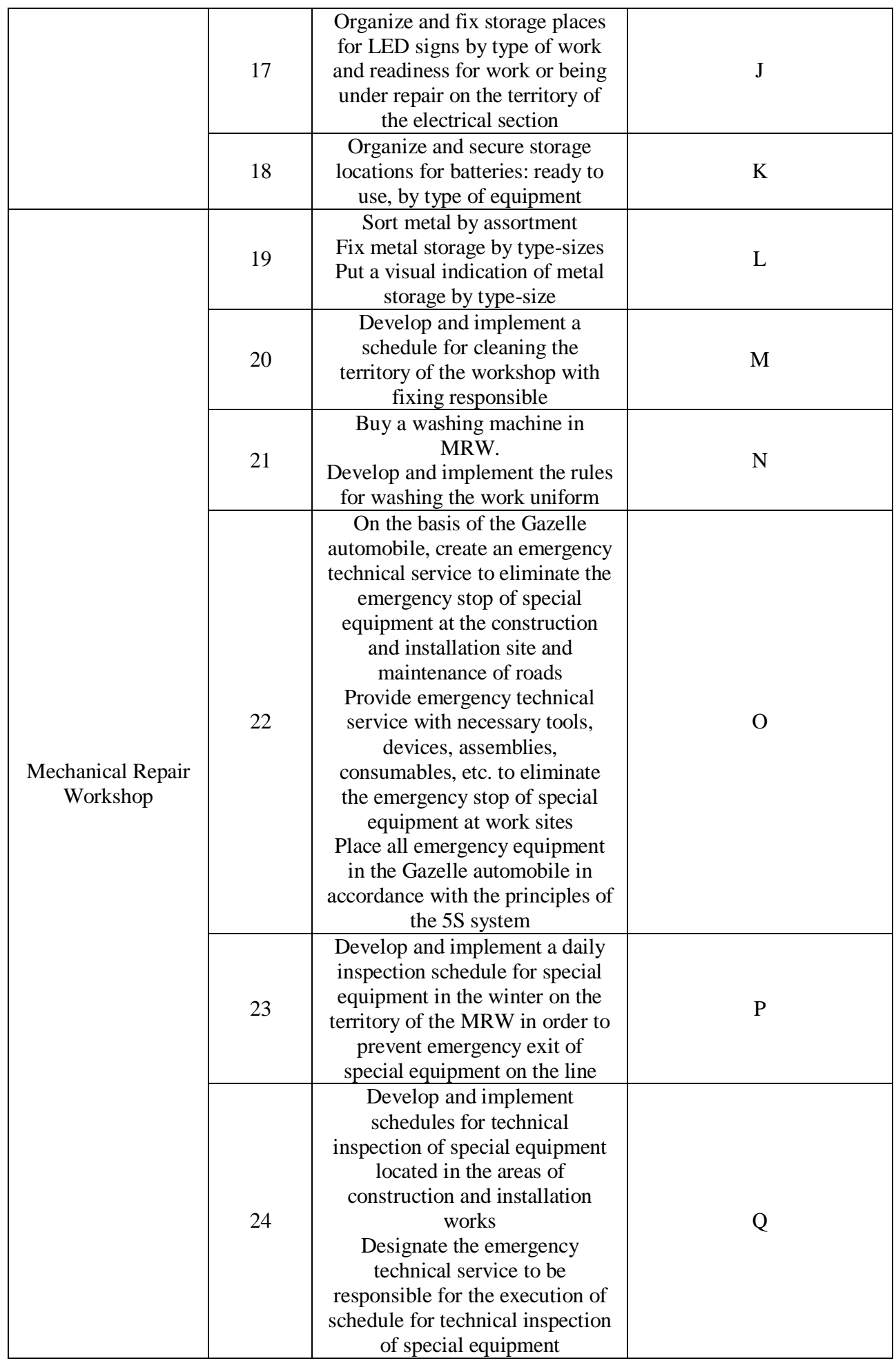


To implement and control the implementation of lean production in the road-building company DRSU-1 of JSC TODEP, a schedule was drawn up taking into account the timing of activities and assigned responsible persons (table 3).

Table 3. Schedule of measures to address identified problems in the reference area "repair and mechanical workshop" DRSU-1 JSC TODEP.

\begin{tabular}{|c|c|c|c|c|c|}
\hline \multirow{2}{*}{ Problem } & \multirow{2}{*}{ Measure } & \multirow{2}{*}{ Responsible person } & \multicolumn{2}{|c|}{ Period of execution } & \multirow{2}{*}{$\begin{array}{c}\text { Date of } \\
\text { monitoring }\end{array}$} \\
\hline & & & (plan) & (fact) & \\
\hline 1 & $\overline{\mathrm{A}}$ & Locksmith of MRW & 29.07 .19 & 29.07 .19 & 04.10 .19 \\
\hline 2 & A & $\begin{array}{l}\text { Locksmith of MRW } \\
\text { Specialist of DCM } \\
\text { (department of chief } \\
\text { mechanic) }\end{array}$ & 05.08 .19 & 05.08 .19 & 04.10 .19 \\
\hline 3 & B & $\begin{array}{l}\text { Locksmith of MRW } \\
\text { Specialist of DCM }\end{array}$ & 05.08 .19 & 05.08 .19 & 04.10 .19 \\
\hline 4 & $\mathrm{C}$ & $\begin{array}{l}\text { Locksmith of MRW } \\
\text { Specialist of DCM }\end{array}$ & 08.08.19 & 08.08.19 & 04.10 .19 \\
\hline 5 & $\mathrm{D}$ & $\begin{array}{l}\text { Locksmith of MRW } \\
\text { Specialist of DCM }\end{array}$ & 12.08 .19 & 12.08 .19 & 04.10 .19 \\
\hline 6 & $\mathrm{E}$ & $\begin{array}{l}\text { Locksmith of MRW } \\
\text { Specialist of DCM }\end{array}$ & 15.08 .19 & 15.08 .19 & 04.10 .19 \\
\hline 7 & $\mathrm{~F}$ & $\begin{array}{l}\text { Locksmith of MRW } \\
\text { Specialist of DCM }\end{array}$ & 29.07.19 & 29.07.19 & 04.10 .19 \\
\hline 8 & $\mathrm{~F}$ & $\begin{array}{l}\text { Locksmith of MRW } \\
\text { Specialist of DCM }\end{array}$ & 05.08 .19 & 05.08 .19 & 04.10 .19 \\
\hline 9 & $\mathrm{~F}$ & $\begin{array}{l}\text { Locksmith of MRW } \\
\text { Specialist of DCM }\end{array}$ & 05.08 .19 & 05.08 .19 & 04.10 .19 \\
\hline 10 & $\mathrm{~F}$ & $\begin{array}{l}\text { Locksmith of MRW } \\
\text { Specialist of DCM }\end{array}$ & 05.08 .19 & 05.08 .19 & 04.10 .19 \\
\hline 11 & G & $\begin{array}{l}\text { Locksmith of MRW } \\
\text { Specialist of DCM }\end{array}$ & 13.08 .19 & 13.08 .19 & 04.10 .19 \\
\hline 12 & $\mathrm{H}$ & $\begin{array}{l}\text { Locksmith of MRW } \\
\text { Specialist of DCM }\end{array}$ & 14.08.19 & 19.08 .19 & 04.10 .19 \\
\hline 13 & I & Electrician of MRW & 29.07 .19 & 29.07 .19 & 04.10 .19 \\
\hline 14 & I & Electrician of MRW & 05.08 .19 & 05.08 .19 & 04.10 .19 \\
\hline 15 & I & Electrician of MRW & 05.08 .19 & 05.08 .19 & 04.10 .19 \\
\hline 16 & I & Electrician of MRW & 05.08 .19 & 05.08 .19 & 04.10 .19 \\
\hline 17 & $\mathrm{~J}$ & Electrician of MRW & 08.08 .19 & 08.08 .19 & 04.10 .19 \\
\hline 18 & $\mathrm{~K}$ & Electrician of MRW & 12.08 .19 & 12.08 .19 & 04.10 .19 \\
\hline 19 & $\mathrm{~L}$ & Specialist of DCM & 19.08.19 & 19.08.19 & 04.10 .19 \\
\hline 20 & $\mathrm{M}$ & Specialist of DCM & 19.08 .19 & 19.08 .19 & 04.10 .19 \\
\hline 21 & $\mathrm{~N}$ & Specialist of DCM & 19.08 .19 & 19.08 .19 & 04.10 .19 \\
\hline 22 & $\mathrm{O}$ & $\begin{array}{c}\text { Chief mechanical } \\
\text { engineer }\end{array}$ & 22.08 .19 & 26.08 .19 & 04.10 .19 \\
\hline 23 & $\mathrm{P}$ & Specialist of DCM & 23.08 .19 & 23.08 .19 & 04.10 .19 \\
\hline 24 & $\mathrm{Q}$ & Specialist of DCM & 26.08 .19 & 26.08 .19 & 04.10 .19 \\
\hline
\end{tabular}

\section{Conclusions}

Practical use of the 5S lean manufacturing tool and the accompanying visualization tool allowed us to achieve following results in the construction and installation works of the company:

- increasing labor productivity and overall performance;

- reduction of losses of working time; 
- lower costs;

- reducing the duration of cycles of construction and installation works;

- reducing training and maintenance of specialized equipment.

Also during the survey, company employees noted positive results after the implementation of measures such as: reduced fatigue, reduced injuries at the workplace, increased job satisfaction, and creation of a safe and convenient workplace.

However, it should be noted that the use of lean manufacturing tools requires constant monitoring of the effectiveness of measures and improvement. At the same time, it is important to promptly fix the ongoing changes through updating current standards.

\section{References}

1. M. Rother, Toyota Kata. Leadership, management and employee development to achieve outstanding results (2014)

2. J. Liker, DAO TOYOTA: 14 principles of management of a leading company in the world (2006)

3. L. Muris, G. Moacir, International Journal Production Economics, 125 (2010)

4. E. Frackleton, R. Girbig, D. Jacquemont, A. Singh, The lean m anagement enterprise, 79-88 (2014)

5. I. Antonova, G. Akhmadeeva, Baltic Humanitarian Magazine, 2(7), 51-53 (2014)

6. O. Anutova, L. Fedoskina, System management, 1(14) (2012)

7. J. Woomek, D. Jones, Lean Manufacturing: How to Get Rid of Losses and Make Your Company Prosperous (2008)

8. N. Davydova, Lean Manufacturing (2012)

9. S. Zinchenko, Almanac "Production Management", 1, 11-16 (2013)

10. M. Imai, Kaizen: the key to the success of Japanese companies (2004)

11. N. Konoshenko, Almanac "Production Management, 3, 27-34 (2013)

12. D. Markov, N. Markov, V. Popov, Lean and responsive production (2018)

13. A. Cheah, W. Wong, Q. Deng, Int. conf. on Industrial Engineering and Operations Management, 2091-2099 (2012)

14. A. Dutta, S. Banerjee, International Journal of Research in Business Management, 2(4), 27-36 (2014)

15. A. Abrosimova, P. Shalabaev, Russian Entrepreneurship, 24 (246), 78-83 (2013)

16. E. Kondratyev, M. Milovanov, Management in Russia and abroad, 5, 49 - 56 (2014)

17. K. Safronov, Problems of theory and practice of management, 12, 114-119 (2015)

18. O. Turovets, V. Rodionova, Production Organizer, 3 (62), 12-18 (2014)

19. H. Chang, C. Huang, C. Torng, International Journal of Innovation, Management and Technology, 4(2), 248 (2013) URL: http://dx.doi.org/10.7763/IJIMT.2013.V4.400

20. G. Dominici, F. Palumbo, Systemic Practice and Action Research, 26(2), 153-171 (2013) URL: http://dx.doi.org/10.1007/s11213-012-9242-z 